\title{
Proterozoic tectonics from the Northern domain of the Eastern Ghats Belt
}

\author{
S.R.BEHERA ${ }^{1 *}$, L.SAHA $^{1}$, \\ D.K.PAL ${ }^{2}$ AND A.K.CHAMPATI ${ }^{3}$
}

${ }^{1}$ Indian Institute of Technology,Roorkee,India

(*soumya7580@gmail.com,saha.lopamudra@gmail.com)

Indian Institute of Technology(ISM),Dhanbad,India

(anilchampati02@gmail.com)

The northern domain of the Eastern Ghats Belt in eastern India preserve multiply deformed khondalites interlayered with the charnockites. EPMA chemical ages of the monazite from the garnet-sillimanite-biotite bearing khondalites yield two peaks at $\sim 1046 \mathrm{Ma}$ and $\sim 920-870 \mathrm{Ma}$. The two age peaks are correlated with first generation of partial melting and a second generation garnet formation. The charnockites interlayered with the khondalites have also undergone partial melting. The monazite ages yielded from the charnockites yield crystallization ages between $\sim 1041-997 \mathrm{Ma}$, implying a genetic link between the first stage of melt generation within the khondalites in the sillimanite stability field with the charnockite generation. Monazites from the migmatitic charnockites yield second peak at $2934-884 \mathrm{Ma}$, also recorded from the khondalites, indicating that the two lithounits underwent a partial melting event during the time frame i.e. during Rodinia supercontinent formation when the belt was part of Rayner Complex. A third monazite population within the charnockites yield ages ranging from 750-740 Ma which is correlated with Rodinia breakup and formation of the extensional Mahanadi Shear Zone at the southern margin of the northern belt of the EGB. 